\title{
PENGARUH METODE DAN PENDEKATAN PEMBELAJARAN TERHADAP PENGUASAAN KONSEP MATEMATIKA
}

\author{
UKTI LUTVAIDAH \\ uktilutvaidah03@gmail.com \\ Program Studi Arsitektur, Fakultas Teknik, Matematika dan IPA \\ Universitas Indraprasta PGRI
}

\begin{abstract}
Abstrak. Tujuan penelitian ini adalah untuk mengetahui pengaruh metode pembelajaran dan pendekatan pembelajaran terhadap penguasaan konsep matematika siswa. Metode yang digunakan dalam penelitian ini adalah metode eksperimen. Subjek penelitian sebagai populasi seluruh siswa SMP Negeri di Kota Tegal dengan populasi terjangkau siswa di SMP Negeri 17 dan SMP Negeri 18 Kota Tegal dan sampel dipilih secara random 120 orang. Penelitian dilaksanakan mulai 22 Oktober sampai 20 November 2014. Data yang digunakan diperoleh melalui teknik tes sertadianalisis menggunakan analisis kuantitatif dengan teknik anava dua jalan. Dalam hal ini perhitungan hipotesis menggunakan SPSS 20.0. Hasil penelitian diperoleh: (1) Terdapat pengaruh yang sangat signifikan pengaruh metode pembelajaran terhadap penguasaan konsep Matematika siswa. (2) Terdapat pengaruh pendekatan pembelajaran yang signifikan terhadap penguasaan matematika siswa. (3) Tidak terdapat pengaruh yang signifikan interaksi metode pembelajaran dan pendekatan pembelajaran terhadap penguasaan konsep Matematika siswa. Hasil penelitian menunjukkan bahwa penguasaan konsep matematika dengan menggunakan metode pembelajaran Complette Sentence dan pendekatan pembelajaran konsep lebih tinggi dibandingkan dengan pendekatan pembelajaran proses.
\end{abstract}

Kata Kunci. Metode Pembelajaran, Pendekatan Pembelajaran, Penguasaan Konsep Matematika

\section{PENDAHULUAN}

Pendidikan merupakan sarana terpenuhinya proses belajar manusia. Tanpa pendidikan manusia tidak mampu mengembangkan fitrahnya sebagai insan pedagogik yang perlu dididik dan mendidik. Namun, suatu pendidikan akan mempunyai mutu yang tinggi apabila guru mempunyai mutu yang tinggi pula. Sedangkan mutu guru sangat ditentukan oleh pemahamannya tentang komponen, pendekatan, dan berbagai metode pengajaran yang diterapkan dalam proses pembelajaran. Usaha-usaha guru dalam mengatur dan menggunakan berbagai variabel pengajaran merupakan bagian penting dalam keberhasilan siswa mencapai tujuan yang direncanakan. Oleh karena itu pemilihan metode, strategi dan pendekatan dalam situasi kelas yang bersangkutan sangat penting. Upaya pengembangan strategi mengajar tersebut berlandas pada pengertian bahwa mengajar merupakan suatu upaya memberikan bimbingan kepada siswa untuk melakukan kegiatan belajar.

Dalam setiap mengikuti proses pembelajaran di sekolah sudah pasti setiap siswa mengharapkan mendapatkan hasil belajar yang baik, sebab hasil belajar yang baik dapat membantu siswa dalam mencapai tujuannya. Hasil belajar yang baik hanya dicapai melalui proses belajar yang baik pula. Jika proses belajar tidak optimal sangat sulit diharapkan terjadinya hasil belajar yang baik. Tujuan dalam pembelajaran matematika yang dianggap penting oleh guru adalah pemahaman konsep matematika. Pemahaman konsep dalam matematika merupakan hal yang paling mendasar dalam mempelajari matematika. Dengan memahami konsep, siswa bisa mengembangkan kemampuannya 
dalam belajar matematika dan menerapkan konsep tersebut untuk menyelesaikan permasalahan matematis dan mengaitkan konsep dengan konsep yang lain.

Matematika selama ini dianggap pelajaran yang sulit oleh sebagian siswa, bahkan ada siswa yang merasa takut, bosan dan tidak tertarik pada mata pelajaran matematika. Kurangnya rasa ingin tahu dan ketidak kritisan yang terdapat dalam diri siswa dan kecenderungan siswa belajar hanya dengan menghafal rumus saja tanpa mengetahui dari mana rumus tersebut diperoleh serta sikap siswa yang terkadang kurang jujur dalam belajar merupakan penyebab yang mengakibatkan hasil belajar yang dicapai siswa belum optimal, matematika menjadi momok yang menakutkan bagi para siswa terutama disaat ulangan atau ujian sekolah.

Kesulitan yang dialami siswa tidak hanya disebabkan oleh faktor internal atau faktor siswa itu sendiri, tetapi juga disebabkan oleh faktor eksternal yakni kurangnya usaha guru dalam menciptakan situasi yang dapat membawa siswa tertarik untuk belajar matematika. Bahkan masih banyak guru yang menggunakan pola pembelajaran dimana cenderung "text book oriented" dalam arti menyampaikan materi sesuai dengan apa yang tertulis didalam buku. Cara pembelajaran cenderung monoton dan hanya menggunakan metode ceramah dan salah satu model pembelajaran yang umum diterapkan oleh guru dalam kelas adalah pembelajaran konvesional sehingga materi yang disampaikan menjadi sulit dipahami siswa.

\section{TINJAUAN PUSTAKA}

\section{Penguasaan Konsep Matematika}

Seorang siswa dikatakan telah menguasai konsep apabila ia telah mampu memahami, mengenali dan mengabstraksi sifat yang sama tersebut, yang merupakan ciri khas dari konsep yang dipelajari, dan telah mampu membuat generalisasi terhadap konsep tersebut. Penguasaan konsep matematika adalah hasil belajar proses untuk memahami, mengenali, atau mengabstraksikan suatu kejadian agar bersifat umum melalui pengalaman, definisi atau pengamatan langsung yang bertahap.

Siswa dapat membangun konsep dengan cara pengamatan atau membayangkan sesuatu yang kongkret terlebih dahulu. Ciri-ciri siswa yang sudah menguasai konsep antara lain: (1) mengetahui ciri-ciri suatu konsep, (2) mengetahui beberapa contoh dan bukan contoh dari konsep tersebut, (3) mengenal sejumlah sifat-sifat dan esensinya dapat menggunakan hubungan antar konsep, (4) dapat mengenal hubungan antar konsep, (5) dapat mengenal kembali konsep itu dalam berbagai situasi, (6) dapat menggunakan konsep dalam menyelesaikan masalah matematika.

\section{Metode Pembelajaran}

Uno \& Mohamad (2012: 7) mengemukakan pendapatnya yaitu "Metode pembelajaran didefinisikan sebagai cara yang digunakan guru dalam menjalankan fungsinya dan merupakan alat untuk mencapai tujuan pembelajaran”.Metode pembelajaran dapat dianggap sebagai suatu prosedur atau proses yang teratur, suatu jalan atau cara yang teratur untuk melakukan kegiatan pembelajaran. Setiap materi pembelajaran tidak dapat menggunakan metode pembelajaran yang sama, oleh karena itu sebelum mengajar seorang guru harus memilih metode pembelajaran yang sesuai dengan materi. Adapun prinsip dalam memilih metode pembelajaran yang dikemukakan oleh Bachtiar Rifva'i (dalam Mira Seplitasari: 2013) yaitu:

1) Asas maju kelanjutan (continous progress) yang artinya memberi kemungkinan pada murid untuk mempelajari sesuatu sesuai dengan kemampuannya. 
2) Penekanan pada belajar sendiri, artinya anak-anak diberikan kesempatan untuk mempelajari dan mencari bahan pelajaran lebih banyak lagi daripada yang diberikan oleh guru.

3) Bekerja secara team, dimana anak mengerejakan sesuatu pekerjaan yang memungkinkan anak bekerja sama.

4) Multi disipliner, artinya memungkinkan anak-anak untuk mempelajari sesuatu meninjau dari berbagai sudut. Misalnya masalah rambut gonderong dapat dilihat dari sudut kesehatan dan pandangan orang.

5) Fleksibel, dalam arti dapat dilakukan menurut keperluan dan keadaan.

Metode pembelajaran banyak macamnya antara lain metode ceramah, metode tanya jawab, metode kelompok, metode sosiodrama, metode diskusi, metode problem solving dan masih banyak lagi. Sedangkan dalam alam penelitian ini, penulis menggunakan metode pembelajaran guided note taking dan complette sentence.

Metode pembelajaran guided note taking merupakan metode pembelajaran yang menggunakan pendekatan pembelajaran kooperatif (cooperative learning). Pembelajaran kooperatif (cooperative learning) adalah segala bentuk pembelajaran yang memungkinkan siswa berperan secara aktif dalam proses pembelajaran itu sendiri baik dalam bentuk interaksi antar siswa maupun siswa dengan guru dalam proses pembelajaran tersebut.

Secara terminolog (dalam Efendi Pakpahan. 2014) guide note taking adalah strategi dimana seorang guru menyiapkan suatu bagan, skema (handout) sebagai media yang dapat membantu siswa dalam membuat catatan ketika seorang guru sedang menyampaikan pelajaran dengan metode ceramah

Langkah - langkah pembelajaran dengan metode pembelajaran guided note taking adalah sebagai berikut:

1) Memberi bahan ajar misalnya berupa handout kepada siswa

2) Materi ajar disampaikan dengan metode ceramah.

3) Mengosongi sebagian poin-poin yang penting sehingga terdapat bagian-bagian yang kosong dalam handout tersebut.

Menurut Purnomo (2012) menyatakan bahwa: Model Pembelajaran Complette Sentence merupakan rangkaian prosespembelajarann yang diawali dengan menyampaikan materi ajar oleh guru, atau dengan penganalisaan terhadap modul yang telah dipersiapkan, pembagian kelompok yang tidak boleh lebih dari tiga orang dengan kemampuan yang heterogen, pemberian lembar kerja yang berisi paragraf yang belum lengkap, lalu diberikan kesempatan kepada siswa untuk berdiskusi dan diakhiri dengan pengambilan kesimpulan.

Langkah-langkah dalam metode pembelajaran Complette Sentence, yaitu:

1) Mempersiapkan lembar kerja siswa dan modul.

2) Guru menyampaikan kompetensi yang ingin dicapai.

3) Guru menyampaikan materi secukupnya atau siswa disuruh membacakan buku atau modul dengan waktu secukupnya.

4) Guru membentuk kelompok 2 atau 3 orang secara heterogen.

5) Guru membagikan lembar kerja yang berupa paragraf yang kalimatnya belum lengkap.

6) Siswa berdiskusi untuk melengkapi paragraf dengan kunci jawaban yang tersedia.

7) Siswa berdiskusi secara berkelompok.

8) Setelah jawaban didiskusikan, jawaban yang salah diperbaiki. Tiap siswa membaca sampai mengerti atau hafal.

9) Kesimpulan. 


\section{Pendekatan Pembelajaran}

Pendekatan pembelajaran merupakan aktifitas guru dalam memilih kegiatan pembelajaran. Tiap pendekatan pembelajaran tersebut mempunyai karakteristik tertentu, dan berbeda antara satu dengan yang lainnya sesuai dengan fungsi dan tujuan tiap pendekatan. Pendekatan pembelajaran tentu tidak kaku harus menggunakan pendekatan tertentu, tetapi sifatnya lugas dan terencana. Artinya memilih pendekatan disesuaikan dengan kebutuhan materi ajar yang dituangkan dalam perencanaan pembelajaran.

Menurut Sagala (2012: 71) Pendekatan konsep merupakan suatu pendekatan pengajaran yang secara langsung menyajikan konsep tanpa memberi kesempatan kepada siswa untuk menghayati bagaimana konsep itu diperoleh. Konsep diperoleh dari fakta, peristiwa, pengalaman, melalui generalisasi dan berfikir abstrak.Konsep memiliki banyak arti tetapi dalam kegiatan belajar mengajar, konsep adalah akibat dan suatu hasil belajar, misal suatu saat seseorang belajar mengenal kesimpulan benda-benda dengan jalan membedakan satu sama lain. Jalan lain yang dapat ditempuh adalah memasukan suatu benda kedalam suatu kelompok tertentu dan mengemukakan beberapa contoh dan kelompok itu yang dinyatakan sebagai jenis kelompok tersebut. Jalan yang kedua inilah yang memungkinkan seseorang mengenal suatu benda atau peristiwa sebagai suatu anggota kelompok.

Pendekatan proses adalah suatu pendekatan pengajaran memberikan kesempatan kepada siswa untuk ikut menghayati proses penemuan atau penyusunan suatu konsep sebagai suatu keterampilan proses (Afrial, 2012). Pendekatan ini dilatar belakangi oleh konsep-konsep belajar menurut teori Naturalisme-Romantis" dan teori kognitif gestal. Naturalisme-romantis menekankan kepada aktifitas siswa. Dan teori kognitif gestal menekankan pemahaman dan kesatupaduan yang menyeluruh.

\section{METODE}

Pada penelitian ini menggunakan metode eksperimen. Sudjana (2009: 56) menyatakan bahwa pada penelitian eksperimen peneliti harus melakukan manipulasi atau perlakuan terhadap variabel bebas, melakukan pengukuran sendiri terhadap variabel bebas dan variabel terikat. Dimana variabel bebasnya ada dua yaitu metode pembelajaran $\left(\mathrm{X}_{1}\right)$ dan pendekatan pembelajaran $\left(\mathrm{X}_{2}\right)$ serta variabel terikatnya yaitu penguasaan konsep matematika (Y).Penelitian ini menggunakan metode eksperimen dengan disain treatmen by level factorial $2 \times 2$.

\section{HASIL DAN PEMBAHASAN}

Penelitian yang dilaksanakan di SMP Negeri Kota Tegal yaitu: SMP Negeri 17 Kota Tegal dan SMP Negeri 18 Kota Tegal sebagai objek penelitian, terdapat 120 orang. Data diambil melalui tes pilihan ganda sebanyak 30 soal dan lama waktunya 2 x 45 menit, setiap soal terdiri dari 4 pilihan yaitu: a, b, c, dan d.Perhitungan data hasil penelitian dilakukan dengan menggunakan program olah data yaitu "SPSS 20.0".Adapun hasilnya sebagai berikut. 
Tabel 1.Hasil Perhitungan Skor Penguasaan Konsep Matematika

\begin{tabular}{|c|c|c|c|}
\hline \multirow{2}{*}{$\begin{array}{l}\text { Pendekatan } \\
\text { Pembelajaran(B) }\end{array}$} & \multicolumn{2}{|c|}{ Metode Pembelajaran (A) } & \multirow[t]{2}{*}{ Jumlah } \\
\hline & $\begin{array}{l}\text { Guided Note } \\
\text { Taking }\left(\mathrm{A}_{1}\right)\end{array}$ & $\begin{array}{c}\text { Complette } \\
\text { Sentence }\left(\mathrm{A}_{2}\right)\end{array}$ & \\
\hline \multirow{3}{*}{$\begin{array}{l}\text { Konsep } \\
\left(\mathrm{B}_{1}\right)\end{array}$} & $\bar{X}=74,50$ & $\bar{X}=85,13$ & $\bar{X}=79,65$ \\
\hline & $S=5,243$ & $S=6,124$ & $S=7,778$ \\
\hline & $n=32$ & $n=30$ & $n=62$ \\
\hline \multirow{3}{*}{$\begin{array}{l}\text { Proses } \\
\left(\mathrm{B}_{2}\right)\end{array}$} & $\bar{X}=72,00$ & $\bar{X}=83,47$ & $\bar{X}=77,93$ \\
\hline & $S=4,846$ & $S=5,469$ & $S=7,795$ \\
\hline & $n=28$ & $n=30$ & $n=58$ \\
\hline \multirow[t]{3}{*}{ Jumlah } & $\bar{X}=73,33$ & $\bar{X}=84,30$ & $\bar{X}=78,82$ \\
\hline & $S=5,174$ & $S=5,901$ & $S=7,801$ \\
\hline & $n=60$ & $n=60$ & $n=120$ \\
\hline
\end{tabular}

Dari tabel 1, Dari penjelasan deskripsi kelompok eksperimen dan kelompok kontrol di atas maka untuk kategori pemberian metode pembelajaran guided note taking pada siswa dengan pendekatan pembelajaran konsep memiliki nilai rata-rata lebih tinggi daripada dengan pendekatan pembelajaran proses. Begitu pula untuk kategori pemberian pemberian metode pembelajaran complette sentence pada siswa dengan pendekatan pembelajaran konsep memiliki nilai rata-rata lebih tinggi daripada dengan pendekatan pembelajaran proses. Dengan demikian dapat diartikan pemberian metode pembelajaran pada guided note taking dan complette sentence dapat meningkatkan penguasaan konsep matematika.

Pada uji persyaratan normalitas, diperoleh bahwa semua sampel pada penelitian iniberdistribusi normal yang berarti sampel berasal dari populasi yang berdistribusi normal sehingga sampel telah mewakili karakteristik populasi. Sedangkan pada uji homogenitas dapat disimpulkan bahwa antar kelompok $A_{1} B_{1}, A_{1} B_{2}, A_{2} B_{1}$, dan $A_{2} B_{2}$ tehadap penguasaan konsep matematika $(\mathrm{Y})$ berasal dari populasi yang homogen.

Pengujian hipotesis penelitian ini dilakukan dengan teknik analisis Anava dua jalan dengan bantuan program SPSS. Setelah dilakukan perhitungan jika kemudian ditemukan adanya pengaruh interaksi maka dilanjutkan dengan uji Tuckey. Berikut ini adalah hasil pengujiannya.

Tabel 2. Hasil Perhitungan Pengujian Hipotesis Penelitian

Tests of Between-Subjects Effects

Dependent Variable: Penguasaan Konsep Matematika

\begin{tabular}{|l|l|c|l|l|l|}
\hline \multicolumn{1}{|c|}{ Source } & Type III Sum of Squares & Df & Mean Square & \multicolumn{1}{c|}{ F } & Sig. \\
\hline Corrected Model & $\mathbf{3 7 4 3 . 0 3 3}^{\mathbf{a}}$ & $\mathbf{3}$ & $\mathbf{1 2 4 7 . 6 7 8}$ & $\mathbf{4 1 . 3 6 4}$ & $\mathbf{. 0 0 0}$ \\
\hline Intercept & $\mathbf{7 4 3 0 0 1 . 5 8 9}$ & $\mathbf{1}$ & $\mathbf{7 4 3 0 0 1 . 5 8 9}$ & $\mathbf{2 4 6 3 2 . 7 0 3}$ & $\mathbf{. 0 0 0}$ \\
\hline $\mathrm{A}$ & $\mathbf{3 6 5 4 . 9 1 7}$ & $\mathbf{1}$ & $\mathbf{3 6 5 4 . 9 1 7}$ & $\mathbf{1 2 1 . 1 7 1}$ & $\mathbf{. 0 0 0}$ \\
\hline $\mathrm{B}$ & $\mathbf{1 2 9 . 9 1 8}$ & $\mathbf{1}$ & $\mathbf{1 2 9 . 9 1 8}$ & $\mathbf{4 . 3 0 7}$ & $\mathbf{. 0 4 0}$ \\
\hline $\mathrm{A} * \mathrm{~B}$ & $\mathbf{5 . 1 9 7}$ & $\mathbf{1}$ & $\mathbf{5 . 1 9 7}$ & $\mathbf{1 7 2}$ & $\mathbf{. 6 7 9}$ \\
\hline Error & $\mathbf{3 4 9 8 . 9 3 3}$ & $\mathbf{1 1 6}$ & $\mathbf{3 0 . 1 6 3}$ & & \\
\hline Total & $\mathbf{7 5 2 6 9 0 . 0 0 0}$ & $\mathbf{1 2 0}$ & & & \\
\hline Corrected Total & $\mathbf{7 2 4 1 . 9 6 7}$ & $\mathbf{1 1 9}$ & & & \\
\hline
\end{tabular}

a. R Squared $=.517$ (Adjusted R Squared $=.504$ )

1. Terdapat Pengaruh Yang Signifikan Metode Pembelajaran Terhadap Penguasaan Konsep Matematika Siswa Kelas VIII SMP Negeri Kota Tegal 
Hipotesis pertama menyatakan "Terdapat Pengaruh yang signifikan Metode Pembelajaran Terhadap Penguasaan Konsep Matematika”. Berdasarkan hasil pengujian pada tabel Test of Between-Subjuct Effects di atas yang merupakan tabel utama yang mempresentasikan hasil hipotesis yang diajukan peneliti. Dari tabel tersebut, diketahui nilai p-value untuk kategori metode pembelajaran adalah 0,000 (< 0,05 ) dan $\mathrm{F}_{0}=121,171$ maka dapat diartikan terdapat pengaruh yang sangat signifikan metode pembelajaran terhadap penguasaan konsep matematika.

2. Terdapat Pengaruh Yang Signifikan Pendekatan Pembelajaran Terhadap Penguasaan Konsep Matematika Siswa Kelas VIII SMP Negeri Kota Tegal

Hipotesis pertama menyatakan ”Terdapat Pengaruh yang signifikan Pendekatan Pembelajaran Terhadap Penguasaan Konsep Matematika”. Berdasarkan hasil pengujian pada tabel Test of Between-Subjuct Effects di atas yang merupakan tabel utama yang mempresentasikan hasil hipotesis yang diajukan peneliti. Dari tabel tersebut, diketahui nilai p-value untuk kategori pendekatan pembelajaran adalah 0,040 $(<0,05)$ dan $\mathrm{F}_{0}=4,307$ maka dapat diartikan terdapat pengaruh yang signifikan pendekatan pembelajaran terhadap penguasaan konsep matematika.

3. Terdapat Pengaruh Interaksi Yang SignifikanMetode Dan Pendekatan Pembelajaran Terhadap Penguasaan Konsep Matematika Siswa Kelas VIII SMP Negeri Kota Tegal

Hipotesis pertama menyatakan ”Terdapat Pengaruh Interaksi yang signifikan Metode Pembelajaran Dan Pendekatan Pembelajaran Terhadap Penguasaan Konsep Matematika”. Berdasarkan hasil pengujian pada tabel Test of Between-Subjuct Effects di atas yang merupakan tabel utama yang mempresentasikan hasil hipotesis yang diajukan peneliti. Dari tabel tersebut, diketahui nilai p-value untuk kategori ineraksi metode pembelajaran dan pendekatan pembelajaran adalah 0,679 $(>0,05)$ dan $\mathrm{F}_{0}=$ 0,172 maka dapat diartikan terdapat pengaruh yang tidak signifikan interaksimetode pembelajaran dan pendekatan pembelajaran terhadap penguasaan konsep matematika.

\section{PENUTUP}

\section{Simpulan}

1. Terdapat pengaruh yang sangat signifikan metode pembelajaran terhadap penguasaan konsep matematika.

2. Terdapat pengaruh yang signifikan pendekatan pembelajaran terhadap penguasaan konsep matematika.

3. Terdapat pengaruh yang tidak signifikan interaksimetode pembelajaran danpendekatan pembelajaran terhadap penguasaan konsep matematika.

\section{Saran}

1. Disarankan bagi guru, dalam upaya penguasaan konsep matematika, metode pembelajaran dan pendekatan pembelajaran eksperimen merupakan metode yang cukup efektif untuk penguasaan aspek kognitif, afektif dan psikomotorik siswa. Serta guru dapat menguasai metode pembelajaran dan pendekatan pembelajan yang hendak diajarkan sehingga siswa menjadi tertarik dalam belajar matematika.

2. Bagi peserta didik, untuk meningkatkan hasil belajar siswa pada bidang studi matematika, hendaknya peserta didik fokus saat guru menerangkan materi dan sering latihan soal.

3. Hendaknya dilakukan penelitian lanjutan, penelitian ini baru mengungkapkan sebagian kecil permasalahan yang berhubungan dengan penguasaan konsep matematika. Temuan penelitian menunjukan masih banyak faktor yang mempengaruhi penguasaan konsep matematika yang tidak diungkapkan dalam penelitian ini. Faktor ini biasa datang dari dalam diri siswa seperti kecerdasan, minat belajar, dan motivasi 
berprestasi siswa terhadap mata pelajaran matematika. Maupun dari luar diri siswa seperti penggunaan media pembelajaran, profesionalisme guru, dan lain sebagainya.

\section{DAFTAR PUSTAKA}

Fathurrahman \& Sutikno. 2011. Strategi Belajar Mengajar. Bandung: PT. Refika Aditama.

Sabari, Ahmad. 2005. Strategi Belajar Mengajar dan Microteaching. Jakarta: Quantum Teaching.

Sagala, Saeful. 2003. Konsep dan Makna Pembelajaran. Bandung: PT. Alfabeta.

Sugiyono. 2007. Metode Penelitian Pendidikan (Pendekatan Kuantitatif, kualitatif, dan R\&D). Bandung: Alfabeta.

Supardi. 2013. Aplikasi Statistika Dalam Penelitian. Jakarta: PT. Change Publication.

Suparman I. A. 2013. Aplikasi Komputer Dalam Penyusunan Karya Ilmiah. Tanggerang: PT. Pustaka Mandiri.

Uno Hamzah B. 2012. Belajar Dengan Pendekatan PAIIKEM. Jakarta: PT. Bumi Aksara.

Pakparhan, Efendi. Teknik Pembelajaran Guide Note Taking. www.tugasakhiramik.blogspot.com (akses 20 April 2014)

Purnomo, Edi. 2012. Model Pembelajaran Complete Sentece. http: //poyothp.blogspot.com /.../model-pembelajaran-complete-sentence (diakses 20 April 2014)

Seplitsari, Mira. 2013. Makalah Metode Pembelajaran. http: //id.slideshare.net/miraseplitasari/makalah-metode-pengajaran. (diakses 16 Oktober 2014)

Suhaimi, Afrial. 2012. Pendekatan Proses. http: //maistrofisika.blogspot.com/ 2009/05/lt.fisika.html. (diakses 2 November 2014) 